\title{
Dimensional changes occurred in cast for complete dentures evaluated by tri-dimen- sional measurements
}

\author{
Alterações dimensionais ocorridas em modelo para prótese total avaliadas por medições \\ tridimensionais
}

Wildes da Costa MONTEIRO

Professor - Prosthodontics Department - Dentistry School of the Itaúna University - Itaúna - MG - Brazil

\section{Christiano Alves de Lima CORRADI}

Mechanical Engineer of SENAI/CEFET - Itaúna - MG - Brazil

\section{Simonides CONSANI}

Professor - Department of Restorative Dentistry - Piracicaba Dental School - University of Campinas - UNICAMP Piracicaba - SP - Brazil

\section{Wilson Batista MENDES}

PhD student - Dental Materials Program - Piracicaba Dental School - University of Campinas - UNICAMP - Piracicaba - SP - Brazil

\begin{abstract}
This study verified the dimensional changes occurred in stone casts by tri-dimensional design obtained from mathematical calculation. Dental stone casts were made in molds of addition silicone, alginate or impression compound relayed by alginate obtained from an aluminum pattern die. Screws were used to establish reference points of the distances, creating segments for area and volume calculation of the generated figures. Tri-dimensional measurement equipment fitted out with Renishaw PH9 measurement head and TP 200 searcher with $1 \mathrm{~mm}$ diameter was used for this distance measurement. Computer Aided Design system was used to determine the X, Y, Z coordinates, which permitted to get the geometry dimensions. Results were submitted to statistical calculation and study of the differences (5\%). Silicone impression produced casts with smaller dimensional changes and larger repetition capacity. The casts presented small variation of the variables values among the copies, when compared to alginate or impression compound relayed with alginate molds. Alginate produced casts with better copy fidelity, with absolute values of the variables close of the absolute values of the variables of the metallic die. Alginate presented good capacity to copy the metallic die among the impression materials, although in dimensional conditions no similar.
\end{abstract}

\section{UNITERMS}

Impression material; dimensional stability; tri-dimensional measurement; dental stone cast.

\section{INTRODUCTION}

Although the innovations of techniques and materials for preventive dentistry and/or conservatives treatments, still today exist, certainty, people needing mucus-supported complete dentures, that are a solution commonly used by most of the dentists to rehabilitate patient with complete teeth loss. The impression for making of complete prostheses have as purpose the negative reproduction of the alveolar edges and soft tissues, which is the area of establishment of the complete dentures. 5 The regular pressure exercised by the complete dentures on the buccal tissues, as previous showed,11,13 acts as biological incentive, necessary for the healthy maintenance of the alveolar bone and mucous membrane. Manly methods are used to evaluate the dimensional alterations that happen in impressions and stone casts, as profile projector, 1,6 perphilometer,3 
confronter optical microscope, 1 MMTs machines, 4,7-9 and mesh of finite elements.10,12

The purpose of this study was to verify the dimensional changes occurred in dental stone casts obtained from impression for complete denture procedure, by means of tri-dimensional design obtained from mathematical calculation.

\section{Material And Methods}

Forty-five type IV dental stone casts (Durone; Dentsply, Rio de Janeiro, Brazil) were made with silicone (Elite HD; Zhermack, Rovigo, Italy), alginate (Hydrogum; Zhermack), and impression compound (Godibar; Lysanda Dental Products, São Paulo, Brazil) relayed with alginate (Hydrogum; Zhermack) impressions, obtained from a same aluminum pattern die. Seven screws were set in the metallic die to be referential points of linear measurements, to obtain areas and volumes that would be calculated by a tridimensional software. ${ }^{10}$ The tri-dimensional coordinate measurements were made in both stone casts and aluminum pattern die. ${ }^{10}$

Tri-dimensional measurement equipment (Mitutoyo, model BLN 710; Tokyo, Japan) fitted out with measurement head Renishaw PH9 and searcher TP 200 with $1 \mathrm{~mm}$ diameter was used to accomplish the measurements. The equipment associated with a CAD (Computer Aided Design) system permitted the determination of $\mathrm{X}, \mathrm{Y}, \mathrm{Z}$ coordinates or Cartesian axes that is used to get all the geometry dimensions. ${ }^{7}$

A coordinate measurement machine is a mechanical and electronic system, which objective is the obtainment of Cartesian coordinates of points on solid surfaces. It's constituted for a stable and fixed base over that it's assembled the three basics components of its structure that are normally the measure table, the colonnade and the arm. In the arm, in other words, on the side external inferior of the vertical axis $(\mathrm{Z})$ a special sensor is coupled (mechanic, electronic or optical) that will enter in contact with the piece that will be measured, being moved in agreement with the capacity of the machine.

The sensor more used now is the electronic sensor. These sensors are units of very sensitive searching, electronically linked to the digital accountants. When doing contact with the piece that will be measured, the measurement tip moves at an angle and it produces an electric and acoustic sign that freezes the digital indication, showing the value of the coordinate of sensor's position. When data processing systems are used, that sign allows that the computer analyzes the suitable value in the digital accountant. When the system of registration of data is worked, the reading of coordinates is made automatically in three graduate lineal scales that are associated respectively each one of the components that materialize the reference axes. Usually, the registration system is worked mechanically, for the touch of the location mechanism on the surface of the object for measurement. However, there are other registrations systems that are worked by optical systems of location, now just as laser beams contemplated in the surface of the object, avoiding like this the contact with the same. The readings about the lineal scales are still submitted to several corrections, with the objective of eliminating due mistakes, not only to defects of construction of the machine, but also to the variation of the environmental conditions and the other possible specific characteristics. $^{7}$ The movement of each axis is registered by an electronic reading system shown in a digital monitor. In general, the machine is linked to a computer that, besides playing an essential part in the phase of processing of the coordinates, it can still control the equipment during the acquisition of the coordinates. These machines execute the measurement of coordinates according to a process directly based in the concept of system of coordinates in the space. That system of coordinates is materialized by the structure of the machine and for the movement of their components. The dimensional definition of a piece is made geometrically in the threedimensional space. Three perpendicular axes amongst themselves, calls $\mathrm{X}, \mathrm{Y}$ and $\mathrm{Z}$ that define a coordinated system of three dimensions characterize those spaces. So, a point in the space is projected in the reference plan, where two coordinates are defined $(\mathrm{X}, \mathrm{Y})$ and the glide (Z) corresponds to the perpendicular. ${ }^{7}$ For the accomplishment of the three-dimensional measurements, they were positioned screws that, later, they were identified with numbers (Figure 1).

For the accomplishment of this work, the stone casts were fastened in the base or measurement table. The collections of the coordinates of the points of the center of each screw were accomplished. Starting from the coordinates collected in the three-dimensional measurement, the designs of the illustrations were generated, where the measurements and calculations for each model would be accomplished. The amount of collected coordinates was the same for all forty five dental stone casts.

The drawings of each model (Figure 2) were generated through the manual transfer of the coordinates for the program of three-dimensional design Mechanical Desktop, where the mathematical calculation of 
the volumes and subsequent determination of the areas was accomplished, for the mesh of finite elements. ${ }^{12}$ After the transfer of the coordinates, it was accomplished the design of the illustration that best represented the areas of each stone casts to be made calculations. For the determination of each illustration, the points regarding each coordinate were linked through lines and specific arches (Figure 3 )

The segments that linked a point in another were identified, for the accomplishment of its posterior measurement. With the certain illustrations of each model, the extrusion of the area of each illustration was accomplished, with a fixed height of $10 \mathrm{~mm}$ (Figure 4). The objective of this procedure is the construction of

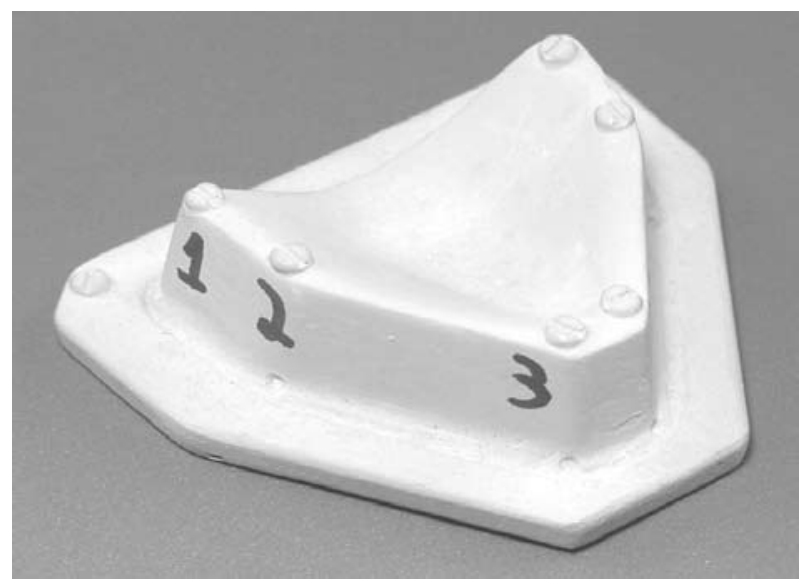

FIGURE 1 - Stone cast with identified screws.

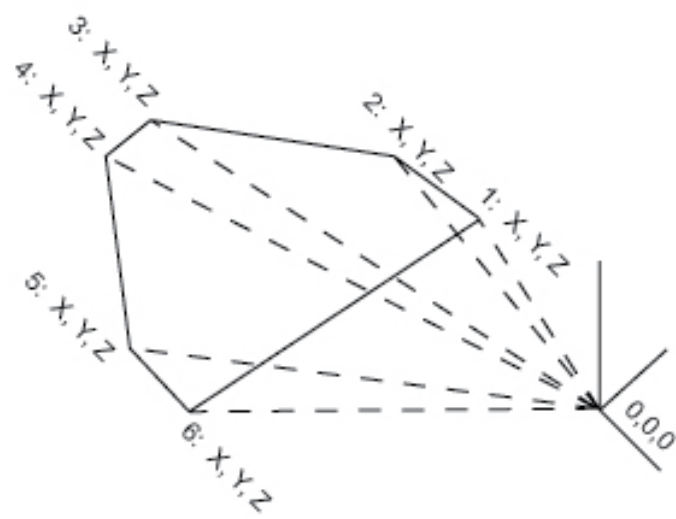

FIGURE 3 -Picture generation for gotten coordinates X, Y and Z. a solid starting from the projected area of each illustration that was built with a mesh of elements finites using software for computer drawing.

Once obtained the volume of the solid, took place the division of this volume for the height standard of $10 \mathrm{~mm}$, used for extrusion of each illustration, this way, being determined the area of the illustration that generated the solid.

\section{Description of the Mathematical Method}

For the statistical control of the variables were made three spreadsheets, of each molding material, containing: ${ }^{10}$

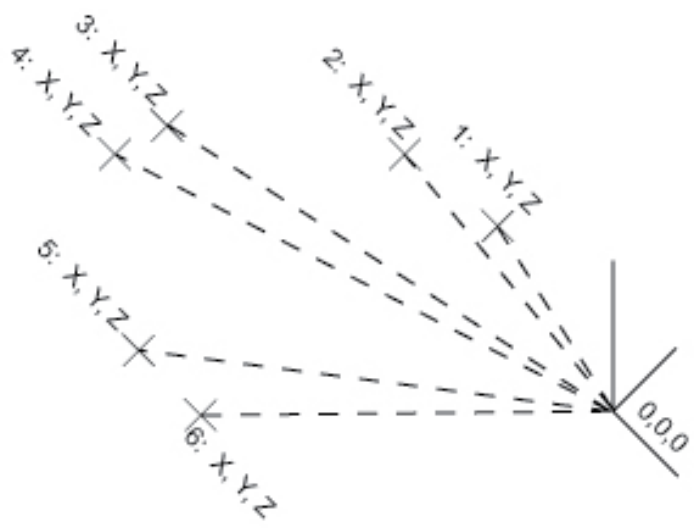

FIGURE 2 - Coordinates X, Y and Z - Software Mechanical Desktop.

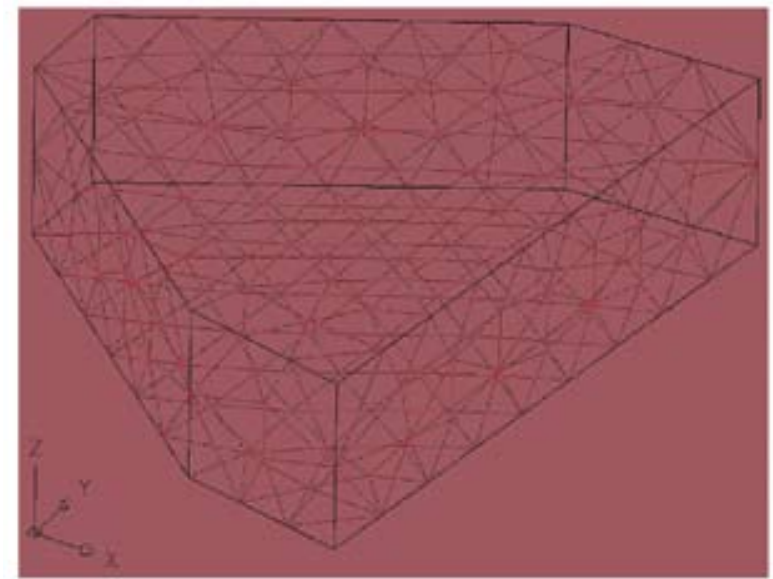

FIGURE 4 - 3D solid (Mesh of Finite Elements). 
- the name of the molding material used for production of the models;

- the number that identifies each one of the fifteen study models;

- value of the perimeter of each one of the fifteen models;

- the value of the calculated area of each one of the fifteen models;

- the values of the coordinates $\mathrm{X}, \mathrm{Y}$ and $\mathrm{Z}$ of each one of the points $1,2,3,4,5$ and 6 for each one of the fifteen models;

- the value of the lengths $1,2,3,4,5$ and 6 of the segments that tie each one of the points, for each one of the fifteen models.

Each spreadsheet has the objective of studying each one of the three materials of alginate, impression compound relayed by alginate and silicone and it was organized in three main areas, in other words, presentation of the results, statistical calculations and study of the differences (Table 5).

The first area of the spreadsheet presents the value of the variables $\mathrm{X}, \mathrm{Y}$ and $\mathrm{Z}$, perimeter, area and length for each one of the fifteen casts manufactured with the material for impression.

The second area presents the value of the variables $\mathrm{X}, \mathrm{Y}$ and $\mathrm{Z}$, perimeter, area and length for the pattern cast, denominated of "goal"; the average of the fifteen values of the variables $\mathrm{X}, \mathrm{Y}$ and $\mathrm{Z}$, perimeter, area and length of the casts; the absolute difference of the values presented in the pattern cast (goal) and of the average of the fifteen casts; and the standard deviation of the values of the variables $\mathrm{X}, \mathrm{Y}$ and $\mathrm{Z}$, perimeter, area and length of the fifteen casts.

The third area presents, basically, the study on the differences among the values of each one of the variables $\mathrm{X}, \mathrm{Y}$ and $\mathrm{Z}$, perimeter, area and length, for each one of the fifteen casts, in relation to the metallic pattern die (goal).

It was also presented in the third area the average of the differences of the variables $\mathrm{X}, \mathrm{Y}$ and $\mathrm{Z}$, perimeter, area and length of the fifteen casts; and the standard deviation of the differences of the variables $\mathrm{X}, \mathrm{Y}$ and $\mathrm{Z}$, perimeter, area and length, of the fifteen casts.

The mathematical calculations used for this study of the variables were accomplished to verify the hypotheses:

"a"- which material presents the absolute values of the variables, as close as possible of the absolute values of the variables of the metallic pattern die "goal", whose characteristic means that the cast in study was capable to copy the metallic die well. "b"- which material presents smaller dispersion or variation of the values of the variables in study. This characteristic translates larger capacity of repetition of the copies generated in the casts, starting from the metallic pattern die "goal".

With the objective to verify the dispersion or variation of the values of the variables in study, that it is the objective " $b$ ", it was used the calculation of the standard deviation. The impression material that best assist the hypotheses "a" and "b", can be considered the best material for impression and subsequent generation of copies.

\section{Obtained Results}

It were made mathematical calculations and statistical analyses (Table 5) to determine which the impression material silicone, alginate or impression compound relayed by with alginate assists better the purposed hypotheses "a" and "b."

\section{Analyze in relation to the objective "A"}

Alginate presented smaller difference average of the values of their variables in relation to the metallic pattern die, following by silicone and impression compound relayed by alginate. After the determination of all the differences, it was made the calculation of the average and of the standard deviation. The result display that the silicone presented, on average, smaller difference of the values of their variables in relation to the metallic pattern die, and the alginate presented very close results to the silicone.

\section{Analysis in RELAtion to the objective "B"}

Silicon presented better result of the dispersion or variation of the values of the variables in study, following by the alginate and impression compound relayed by alginate. With the objective to evidence the result of calculated standard deviation, it was also elaborated a bar graph (Figure 5), that it shows the dispersion values of the variables in study. These results indicate that the silicone is an impression material that presents better dimensional stability of the measures, when accomplished several impression starting from the metallic pattern die. Models made with 


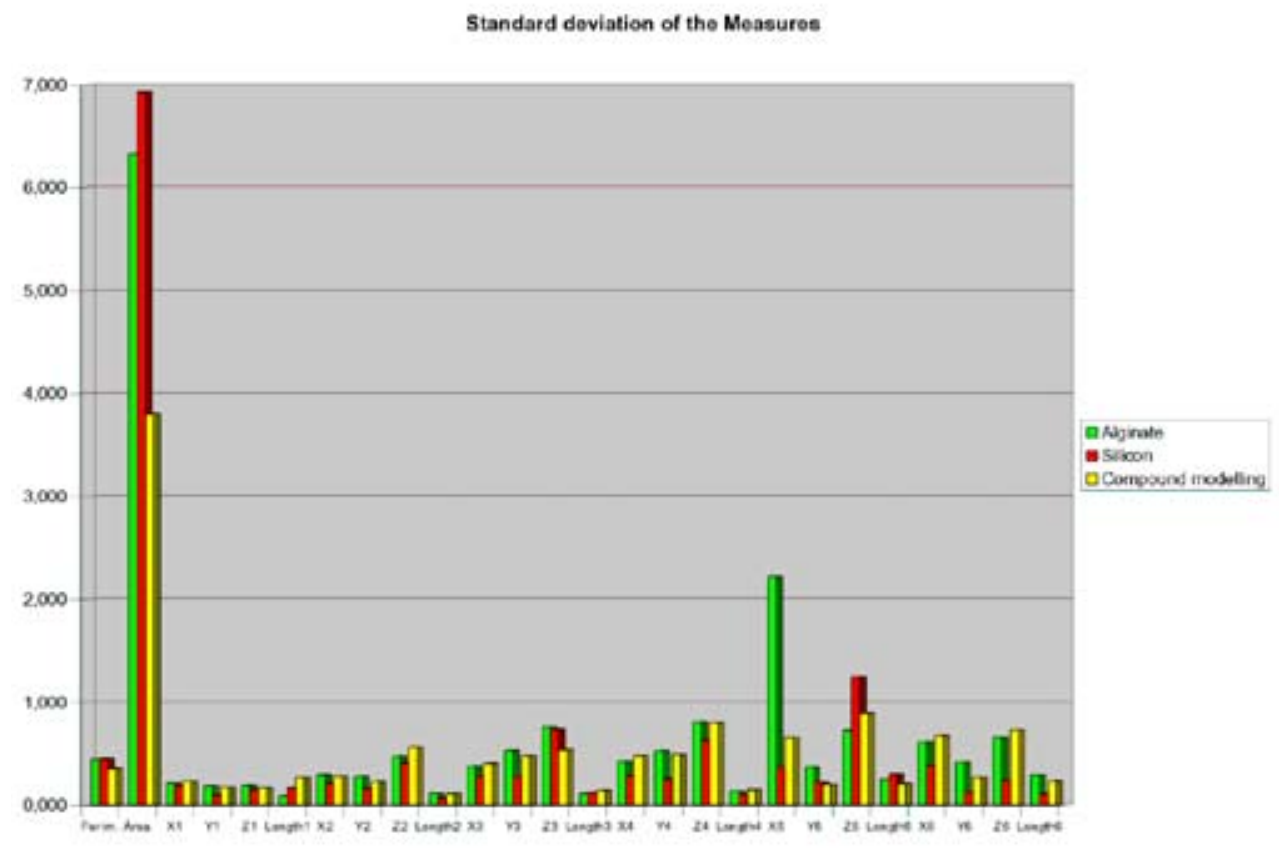

FIGURE 5 - Standard deviation of the measures.

silicone will have smaller variation of their dimensions along several impressions. The result obtained on the standard deviation of the variables means that the manufactured casts will have their closer dimensions amongst themselves, that it is the hypothesis " $b$ ". This result doesn't mean that the manufactured casts will have their closer dimensions of the dimensions of the metallic pattern die, that it is the hypothesis "a".

\section{Conclusion}

Within the limitation of this study, the following conclusions were drawn:
1. Addition silicone impression produced casts with smaller dimensional change and larger repetition capacity. The casts presented small variation of the values of the variables among several copies, when compared to the casts obtained with alginate impression and impression compound relayed by alginate.

2. Alginate produced casts with better copy fidelity, presenting absolute values of the variables close of the absolute values of the variables of the metallic pattern die, when compared to the silicone and impression compound relayed with alginate. Alginate presented good capacity to copy the metallic pattern die, although the casts presented dimensional conditions no similar. 


\section{Resumo}

O estudo verificou as alterações dimensionais ocorridas em modelo de gesso por meio de desenho tridimensional obtido com cálculos matemáticos. Modelos de gesso de uma matriz metálica representando uma maxila desdentada foram obtidos em moldes de silicone por adição, godiva ou godiva reembasada com alginato. Parafusos foram colocados em pontos referenciais para estabelecer as distâncias, criando segmentos para cálculo da área e volume das figuras geradas. Um equipamento para medições tridimensionais com sonda para medição Renishaw PH9 e escaneador TP 200, com ponta ativa de $1 \mathrm{~mm}$ de diâmetro foi usado para medir as distâncias. Um sistema de desenho auxiliado por computador foi usado para determinar as coordenadas $\mathrm{X}, \mathrm{Y}$ e Z, as quais permitiam a captura das dimensões geométricas. Os resultados foram submetidos à análise estatística e ao estudo das comparações (5\%). O molde de silicone produziu modelos com alteração dimensional pequena e grande capacidade de repetição. Os modelos apresentaram valores com pequena variação entre os modelos quando comparados com os modelos feitos em moldes de alginato ou godiva reembasada com alginato. $\mathrm{O}$ alginato produziu moldelos com melhor fidelidade de cópia, com valores absolutos das variáveis próximos dos valores absolutos das variáveis do modelo padrão metálico. O alginato apresentou boa capacidade para copiar o modelo metálico entre os materiais moldadores, embora em condição dimensional não similar.

\section{UNITERMOS}

Materiais para moldagem; estabilidade dimensional; medição tridimensional; modelo de gesso

\section{REFERENCES}

1. Adabo GL, Zanorotti E, Fonseca RG, Cruz CAS. Effect of disinfectant agents on dimensional stability of elastomeric impression materials. J Prosthet Dent.1999;81:621-24.

2. Asgar K. Elastic impression materials. Dent Clin North Am. 1971; 15:81-98.

3. Ayers HD, Phillips RW, Dell A, Henry RW. Detail duplication test used to evaluate elastic impression materials. J Prosthet Dent 1960;10:374-80.

4. Bosch JA. Coordinate Measuring Machines and Systems. $1^{\text {st }}$ ed New York: Marcel Dekker Inc; 1995.

5. Boucher CO. Swenson's complete dentures. 6th.ed. St. Louis: CV Mosby; 1970.p.321-55.

6. Hsu CC, Millstein PL, Stein RS. A comparative analysis of the accuracy of implant transfer techniques. J Prosthet Dent.1993; 69: 588-93.

7. Lin ZC, Liu QY. Selection of coordinate measuring machines by neural network method. Inter J Manufacturing Technol 1997; 13:42-55.

8. Miguel PAC, Abackerli AJ, King TG. A review on methods for probe performance verification. Measurement J 1998; 23:15-33.

9. Miguel PAC, King TG, Davis JE. CMM verification lomms large. Quality Today 1997; 1:8-10.
10. Monteiro WC, Corradi CAL, Domitti SS, Consani S. Tri-dimensional measurements to evaluate dimensional alterations in gypsum patterns for complete dentures. Braz Dental Sci 2003; 6:12-8.

11. Nagle RJ, Sears VH, Silverman SI. Dental Prosthodontics - Complete Dentures. 2nd. ed. Barcelona: Toray; 1965. p.1-543.

12. Sato Y, Abe Y, Okame H, Tsuga K. Finite elements analysis of stress relaxation in soft denture liners. J Oral Rehabil 2000; 27:660-63.

13. Weng BX, Khlevnoy V. Pressure control for complete denture impressions. Oral Health. 1995; 85: 21-7.

Recebido em: 01/02/06

Aprovado em: 05/06/06

Wildes da Costa Monteiro Av. Getúlio Vargas, 622 - sala 301 - Centro 35500-024 - Divinópolis, MG 55 (37) 3221-9440

e-mail: wildesmonteiro@hotmail.com.br 